receipt of papers is not always given. A more uniform lettering of the illustrations might also receive attention, and the adoption of a bold face type for the volume numbers in the lists of references would add to the ease of reading. These criticisms are, however, minor and are points which will probably be dealt with as the journal becomes more mature. The periodical certainly fills a need, and should serve, as the editors point out, actually to help to counteract undue subdivision in physiology by bringing together in one journal many divergent investigations on the nervous system.

\section{Social Applications of Physics}

IN an address on the "Social Applications of Physics" at a symposium at the University of Sydney on September 21, which was published in the Union Recorder (October 7), Prof. O. U. Vonwiller, pointing out that the man of science to-day must consider the bearing of his work on the problems of civilization and recognize his responsibility for some of the economic and social difficulties of the times, suggested these difficulties were due primarily to our inability to accommodate social and economic conditions to the rapidly changing methods of production following the application of scientific discovery. The main cause of these rapid changes was the changed status of the inventor, and while the success of the man of science as inventor had brought many real benefits to mankind, much distress had also arisen because in applying scientific discovery the first consideration was that of financial benefit. Prof. Vonwiller considered we could not continue to ignore ameliorating measures and suggested that the most promising method for dealing with the evils of over-production was to reduce the hours of employment. No satisfactory and lasting improvement in our difficulties could be expected, however, unless we adopted much from the methods of scientific investigation and discovery, with their honesty of inquiry and statement. In economic questions the difficulty of avoiding prejudice, however, was very great, and Prof. Vonwiller did not suggest that the adoption of scientific method would remove all our difficulties, though he appealed strongly for a courageous endeavour to understand and make understood the possibilities and limitations of scientific progress.

\section{Twenty-fifth Anniversary of Laue Diagrams}

LAUE first used his method of $\mathrm{X}$-ray analysis of crystal structure in 1912. The twenty-fifth anniversary of this event has been celebrated by Die Naturvissenschaften by the publication of two interesting articles on the progress made in this branch of crystal chemistry. One, by F. Laves (Naturwiss., 25, 705, 721; 1937), deals with the theory of the method and its development, and mentions its applications, particularly to the determination of atomic distances in crystals. A full account of our present knowledge of the radii of ions and atoms and their separations in crystals, and the dependence of these on the type of linking, is given, and there is a useful bibliography. The second article deals with the use of X-ray interference methods in the investigation of the fine-structure of animal tissues, and is contributed by F. O. Schmitt (Naturwiss., 25, 709 ; 1937). It mentions particularly progress made in the examination of nerve, sinew and muscle, and other tissues in which there is a high degree of orientation of proteins or lipins. It will be recalled that Current Science also had special articles in connexion with this anniversary (see NATURE, 139, 517 ; 1937).

\section{History of Science and Medicine}

WE have received the fourth volume of Osiris, a journal edited by Dr. George Sarton and dealing with the history and philosophy of science. This volume is entitled "Incunabula Scientifica et Medica", by A. C. Klebs, and contains the titles of books on science and medicine printed up to the year 1500 , with references to catalogues indicating where the books may be found. This list is very convenient to students of the history of science and medicine, since it contains information which was previously to be found only in large and expensive library catalogues. The volume is quite a substantial one, having 359 pages, so that it is evident that an unexpected range of material of this class was printed at an early period. In a book purporting to give accurate information on dates of publications, it is somewhat surprising to find the title-page dated 1938, whereas the volume was received in October 1937.

\section{Proposed List of Current Geographical Publications}

More than eight hundred technical and scientific periodicals are received by the library of the American Geographical Society. From these a careful selection of material of geographical interest is made, to be entered in the library's research catalogue. A current index is thereby provided to an extremely important body of geographical material that does not appear in the usual library catalogue. There is thus afforded a continuous, up-to-date record of current material of value not only to geographers but also to geologists, economists, anthropologists, and workers in many other allied fields. So useful has the research catalogue proved to the staff of the Society and to those consult: ing its library that the Society now proposes to make this material more generally available if there is sufficient demand. It is planned to publish ten mimeographed lists a year of the material catalogued during the month (material for July and August to be listed in the following issues). The subscription rate will be $\mathbf{3 . 7 5}$ dollars.

\section{Fisheries Research in Australia}

THE 138-ton motor ship Warreen (an aboriginal name for the sea), built for the fisheries section of the Australian Council for Scientific and Industrial Research, has been launched in Melbourne. The vessel will be used for the study of pelagic fish in the waters around Australia, commencing in the south-eastern seas. The headquarters of the section will be at Port 